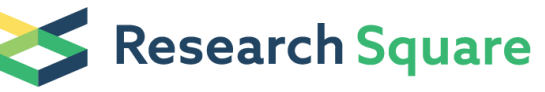 \\ Preprints are preliminary reports that have not undergone peer review. \\ They should not be considered conclusive, used to inform clinical practice, or referenced by the media as validated information.
}

\section{Hydrology, Biogeochemistry and Metabolism in a Semi-Arid Mediterranean Coastal Wetland Ecosystem}

Béchir Béjaoui ( $\square$ bejaoui.bechir@gmail.com )

National Institute of Marine Sciences and Technologies, 2025 Salammbô, Tunis

Hatem Salem

National Institute of Marine Sciences and Technologies, 2025 Salammbô, Tunis

Leila Basti

Faculty of Marine Resources and Environment, Tokyo University of Marine Science and Technology,

Minato, 108-8477, Tokyo

Wafa Feki-Sahnoun

Digital Research Center of Sfax, Technopole of Sfax, PO Box 275, Sakiet Ezzit 3021, Sfax

\section{Sana Dahmani}

University of Applied Sciences for Engineering and Economics in Berlin

\section{Donata Canu}

National Institute of Oceanography and Applied Geophysics, Borgo Grotta Gigante, 42/c, 34010

Sgonico, Trieste

\section{Sihem Benabdallah}

The City University of New York, New York City College of Technology, 300 Jay St, Brooklyn, NY 11201, New York

\section{Reginald Blake}

The City University of New York, New York City College of Technology, 300 Jay St, Brooklyn, NY 11201, New York

\section{Hamidreza Norouzi}

The City University of New York, New York City College of Technology, 300 Jay St, Brooklyn, NY 11201, New York

\section{Cosimo Solidoro}

National Institute of Oceanography and Applied Geophysics, Borgo Grotta Gigante, 42/c, 34010 Sgonico, Trieste

\section{Research Article}

Keywords: Biosphere Reserve, UNESCO World Heritage, Wetlands, Water budget, Nutrient budget, Net Ecosystem Metabolism 
Posted Date: January 26th, 2022

DOI: https://doi.org/10.21203/rs.3.rs-1278908/v1

License: (c) (i) This work is licensed under a Creative Commons Attribution 4.0 International License. Read Full License 
1 Hydrology, Biogeochemistry and Metabolism in a Semi-Arid Mediterranean

\section{Coastal Wetland Ecosystem}

3 Béchir Béjaoui ${ }^{{ }^{*}}$, Hatem Salem ${ }^{1,2}$, Leila Basti ${ }^{3}$, Wafa Feki-Sahnoun ${ }^{4}$, Sana Dahmani ${ }^{1}$, Donata

4 Melaku Canu ${ }^{5}$, Sihem Benabdallah ${ }^{6}$, Reginald Blake$^{7}$, Hamidreza Norouzi ${ }^{7}$, Cosimo

5 Solidoro 5

61 National Institute of Marine Sciences and Technology, University of Carthage, 2025

7 Salammbô, Tunis, Tunisia.

82 Laboratory of Hydraulics and Environment, National Engineering School of Tunis,

9 University of Tunis, BP 37, 1002, Tunis, Tunisia.

103 Faculty of Marine Resources and Environment, Tokyo University of Marine Science and

11 Technology, Minato, 108-8477 Tokyo, Japan.

124 Digital Research Center of Sfax, Technopole of Sfax, PO Box 275, Sakiet Ezzit 3021, Sfax,

13 Tunisia.

145 National Institute of Oceanography and Applied Geophysics, Borgo Grotta Gigante, 42/c,

1534010 Sgonico, Trieste, Italy.

166 Center for Water Research and Technologies, Technople Borj Cedria, BP 273-8020, Tunis,

17 Tunisia.

187 The City University of New York, New York City College of Technology, 300 Jay St,

19 Brooklyn, NY 11201, United States, New York, USA.

20 8. International Center of Theoretical Physics, ICTP, Strada Costiera, Trieste, Italy. 


\section{Corresponding Author:}

\section{Béchir Béjaoui:}

27 National Institute of Marine Sciences and Technologies, University of Carthage, 28 rue du 2

28 Mars 1934 Carthage Salammbô, Tunis, Tunisia.

29 bejaoui.bechir@gmail.com

30 bejaoui.bechir@instm.rnrt.tn

31 Tel: + (216) 71730420

32 Fax: + (216) 71732622

\section{Authors' ORCID}

35 Béchir Béjaoui: 0000-0003-3703-0679

36 Leila Basti: 0000-0002-1327-4452

37 Wafa Feki-Sahnoun: 0000-0003-1688-2071

38 Sihem Benabdallah: 0000-0001-6796-5526

39 Donata Melaku Canu: 0000-0002-1853-2115

40 Reginald Blake: 0000-0001-9974-0663

41 Hamidrea Norouzi: 0000-0003-0405-5108

42 Cosimo Solidoro: 0000-0003-2354-4302

43

44 


\section{Abstract}

46 Experimental and numerical approaches were used to assess the functioning of a flagship coastal

47 wetland ecosystem for improved water management. Very pronounced seasonal contrast in

48 Salinity and Chlorophyll $a$ were found, with high correlation between Chl $a$ and Phosphorus

49 during winter and Chla and Nitrogen during summer. Water and Dissolved Inorganic Phosphorus

50 (DIP) and Dissolved Inorganic Nitrogen (DIN) fluxes exhibited seasonal variation, where the

51 lake is a source of DIN and DIP during the wet season. A considerable anthropogenic-driven

52 amount of nitrogen is transferred into $\mathrm{N}_{2} / \mathrm{N}_{2} \mathrm{O}$ to the atmosphere during the dry season with

53 predominance of denitrification-anammox processes. The primary production is impacted by

54 forcing the respiration of the ecosystem to reduce the Net Ecosystem Metabolism so that the

55 system is functioning as heterotrophic. Climate change and anthropogenic pressures explain the

56 deterioration of water quality and possibly the decrease in populations of Palearctic birds,

57 warranting depollution and effective National Wetland Management Strategies through improved

58 water resources management.

59 Key words: Biosphere Reserve, UNESCO World Heritage, Wetlands, Water budget, Nutrient

60 budget, Net Ecosystem Metabolism

61 


\section{1. Introduction}

63 Wetlands are important wildlife ecosystems that play distinctive and unique roles on a planetary 64 scale in climate regulation, biodiversity, food security, energy, blue carbon, water management, 65 disaster risk reduction, human health, sustainable livelihood, and urban future (Gibbs 2000;

66 Turner et al. 2000; Zedler and Kercher 2005; Euliss et al. 2008; Costanza et al. 2014; Macreadie

67 et al. 2019). They are attractive to many primary and secondary trophic consumers due to their

68 abundant habitats and their high productivity (Basset et al. 2013; Newton et al. 2018, 2020).

69 However, wetlands remain one of the most threatened habitats because of their vulnerability and

70 attractiveness for human development (RAMSAR 2010). Despite recent sustainable management

71 attempts, most wetlands have undergone major disruptions, and the areas of well-conserved

72 aquatic habitats are still declining (Kingsford et al. 2016). In addition to habitat loss and

73 degradation, the main pressures are exerted by reduced watershed inputs due to the damming of

74 rivers and the excess of nutrient inputs and organic matter from urbanization, agriculture and

75 pollution (Newton et al. 2014).

76 Indeed, the pressures of effluents from urban sewage, industry, agriculture, urban development,

77 fishing and aquaculture adversely impact wetland ecosystem ecology and aesthetics as well as

78 public health through a deterioration of water quality (Mitsch and Gosselink 2015; Goudling et al.

79 2019; Newton et al. 2020). Urbanization, the increase of human population, the intensification of

80 agriculture, tourism, land reclamation, the construction of dams, and the overexploitation of

81 biotic and abiotic resources caused a change of the hydrology and the sedimentology cycles of

82 wetland ecosystems as well as the loss of wetland habitat and coastal vegetation (salt marshes,

83 seagrass meadows, and algae beds) that provide nurseries for waterfowls and other species (Beck

84 et al. 2001; Newton et al. 2020). In addition, pressures from invasive species have been 
85 threatening the ecological status, the biodiversity, and the socio-economic services of wetlands

86 (Ayache et al. 2009; Newton et al. 2020). Regardless of their spatial extent, the watershed size

87 and human population, coastal wetland ecosystems provide goods and benefits for human life and

88 welfare. These goods, with their economical, societal, heritage, and scientific values have a

89 positive impact on human well-being (Newton et al. 2014, 2018). The components of the latter

90 include the basic materials for good life, security, health, and social relations. To evaluate their

91 ecological status and to assess their sensitivity to anthropogenic pressures and climate change,

92 numerical and statistical models (Kitsiou and Karydis 2011), and biogeochemical models (Hu

93 2016) have often been used to assess the characteristics as well as the eutrophication mechanisms

94 and water quality of coastal wetlands (Ganju et al. 2016).

95 Globally, up to $70 \%$ of wetlands have been lost since $1900 \mathrm{AD}$, including coastal wetlands which

96 provide higher estimated values of services (Newton et al. 2018). The latter, considered unique

97 ecosystems between the continent and the sea, are characterized by high spatial and temporal

98 variability, and provide the highest ecosystem services along with coral reefs, seagrass meadows,

99 and algae beds (Costanza et al. 2014, Newton et al. 2014, Béjaoui et al. 2016). The extents of the

100 different kind of pressures on wetlands of North Africa are particularly exacerbated as their

101 spatial range has been contracting and their ecological condition deteriorating (Ramdani et al.

102 2011, Junk 2013). Among the coastal ecosystems of North Africa that are exposed to climatic

103 and human pressures is the Tunisian wetland ecosystem - the Ichkeul Lake; this unique Lake is

104 endowed with great national and international importance (Ouni et al. 2020). The Ichkeul Lake is

105 geolocated at the interface between a Mediterranean climate and a semi-arid climate of North

106 Africa. It has long been recognized as one of the most important preserved wetlands in the

107 Mediterranean region and as an important overwintering site of Palearctic waterfowls, with peak

108 winter records of up to 100.000-200.000 birds (Hollis et al. 1986, Casagranda and Boudouresque 
109 2009, Hamdi et al. 2012; http://datazone.birdlife.org/site/factsheet/ichkeul-iba-tunisia/text last

110 accessed September 1, 2021)). The lake also presents a rather spectacular hydrological

111 functioning, with a seasonal reversal of the water exchange with the Bizerte lagoon, which is in

112 turn connected with the sea. Thanks to its high ecological value and the specificity of its

113 hydrological functioning, the Ichkeul wetland is one of the few sites listed under three

114 international conventions namely the Biosphere Reserves of 1977 (UNESCO 2009a), the World

115 Heritage Convention of 1979 (UNESCO World Heritage Centre 2009b) and the Ramsar

116 Convention of 1980 (RAMSAR Convention and Wetlands International 2009). It was ratified as

117 a national park in 1980. However, since the 1980s, this area has been threatened by the 118 construction of dams on the main rivers (Joumine dam in 1983, Ghezala dam in 1984, and

119 Sejnane dam in 1994); this drastically reduced the freshwater inputs to the Lake (Hamdi et al. 120 2012). A sluice was installed in 1993 at the outlet of the lake at the Tinja channel to regulate the 121 seawater fluxes between the lake and the adjacent lagoon of Bizerte. These locks have caused the

122 formation of new sedimentary deposits upstream of the channel (Tamisier et al. 2001).

123 Several studies have been carried out to evaluate the Ichkeul Lake ecological status (Yazidi et al.

124 2017); however, quantitative studies based on numerical analyses are scarce. The present study

125 aims at characterizing the seasonal contrasting state of the Ichkeul Lake. This study is rooted in

126 experimental observations carried out during a 5-month campaign. It quantifies the water, salt

127 and nutrient budgets by applying a Box Model tool and the Land-Ocean Interactions in the

128 Coastal Zone (LOICZ). This work is, therefore, the first to use a Box Model approach in the

129 study of a Southern Mediterranean coastal ecosystem to sustain the management of a RAMSAR 130 coastal wetland via improved water management strategies 


\section{2. Material and methods}

\section{$132 \quad 2.1$ Study area and main features}

133 Ichkeul Lake, located in far Northern Tunisia, is a system of $90 \mathrm{~km}^{2}$ surrounded by $30 \mathrm{~km}^{2}$ of

134 temporary marshes (Tamisier et al. 2001). The Southern shore of the lake is dominated by a

135 limestone mountain - Jebel Ichkeul (Fig. 1). The Ichkeul Lake receives freshwater from a 2,600

$136 \mathrm{~km}^{2}$ catchment area via six main rivers, and it is also linked by the Tinja channel to the coastal

137 Bizerte Lagoon. The channel is about $5 \mathrm{~km}$ long and $3 \mathrm{~m}$ deep during the flood period (Béjaoui et

138 al. 2017), and it ensures the exchange of water and heat between the Ichkeul Lake and the Bizerte

139 Lagoon.

140 This Lake is known for the seasonal fluctuations of water levels and salinity concentrations due

141 to the variation of freshwater inputs between winter and summer, and it is characterized by its

142 very shallow water depth, with a maximum depth of only 2-3 meters during the wet seasons

143 (Casagranda and Boudouresque 2009, Ouni et al. 2020). The water budget in the Ichkeul Lake is

144 controlled by contributions from both marine waters from the Bizerte Lagoon and freshwater

145 from direct rainfall and from its watersheds. During the rainy seasons, a large volume of the lake

146 water spills off to the Bizerte lagoon through the Tinja channel (Affouri and Sahraoui 2017). In

147 summer, high evaporation rates lower the water level and allow seawater to enter to the lake. The

148 wetland is, therefore, characterized by a double seasonal alternation of high-water levels $(2.0 \mathrm{~m}<)$

149 and low salinity $(<8.0)$ in the wet season from October to March due to freshwater from run-off,

150 while it shows a low water levels $(<1 \mathrm{~m})$ and a high salinity $(50 \mathrm{~g} / \mathrm{l}<)$ in the dry season from

151 April to September due to the inflow of sea water (Tamisier et al. 2001, Shaiek 2016, Affouri and 152 Sahraoui 2017). 
153 The Ichkeul region has a Mediterranean climate with mild rainy winters and hot dry summers.

154 The average annual rainfall is about $575.5 \mathrm{~mm} /$ year of which only $4 \%$ fall in the summer period.

155 The mean temperature is about $19{ }^{\circ} \mathrm{C}$ and the potential evaporation is between 1,300 and 1,400

$156 \mathrm{~mm} /$ year (INM 2017).

\section{$157 \quad 2.2$ Experimental observations and statistical assessment}

158 Water sampling at 7 stations (from S1 to S7, Fig. 1) in the Ichkeul Lake was performed during a

159 5-month campaign (November 2016, March, April, May, and August 2017). The locations of the

160 sampling stations were selected according to the environmental and ecological conditions of the

161 Lake.

162 In-situ measurements of water temperature (T), dissolved oxygen (DO), and salinity (S) were

163 carried out by a pre-calibrated multi-parameter Thermo Orion meter. The laboratory analyses of

164 the surface water samples were performed for the ammonium $\left(\mathrm{NH}^{+}\right)$, nitrates $\left(\mathrm{NO}_{3}{ }^{-}\right)$, nitrites

$165\left(\mathrm{NO}_{2}{ }^{-}\right)$and phosphorous $\left(\mathrm{PO}_{4}{ }^{3-}\right)$ using a BRAN and LUEBBE Auto-Analyzer-3, and their

166 concentrations were determined calorimetrically using a UV-visible (6400/6405)

167 spectrophotometer (APHA 1992, Jenway Corporation, UK). Total nitrogen (TN) and total

168 phosphorus (TP) were determined after mineralization into ammonia and orthophosphate,

169 respectively (Rodier et al. 1996). The Chlorophyll $a(\mathrm{Chl} a)$ concentrations were measured using

170 the spectrophotometric method of Lorenzen (1967), following the procedure given by Parsons et

171 al. (1984), after 24-hour extractions in $90 \%$ acetone at $5{ }^{\circ} \mathrm{C}$ in the dark. The dissolved inorganic

172 nitrogen (DIN) and the dissolved inorganic phosphorus (DIP) were computed for further analysis.

\section{$173 \quad 2.3$ Multivariate statistical tool}

174 A Principal Component Analysis (PCA) using R package Ade4 was performed to relate the 175 sampling stations, Chla, physico-chemical and chemical parameters in the wet and dry seasons. 


\subsection{Material budgets model}

177 Budget models are used to assess the budgets of physical and biological variables in coastal

178 ecosystems. The Land Ocean Interaction Coastal Zone (LOICZ) model approach was used to

179 assess water, salt, and non-conservative material budgets in the Lake. This tool has been proven

180 to efficiently describe essential features of lagoon systems in the Mediterranean context (

181 Giordani et al. 2005, Strobl et al. 2009). The LOICZ was used to investigate the impact of

182 Climate Change on the coastal ecosystem and also to evaluate the strain of the anthropological

183 effect (Kremer et al., 2005).

184 The System Ichkeul Lake-Bizerte Lagoon is reproduced by the model as a simple single-layer

185 box, simulating the Ichkeul Lake input-output fluxes on the entry/exit sides of the box,

186 respectively (Fig. 2).

$187 \quad$ 2.4.1 Water budget

188 The water volume of the Lake, $V_{s y s}$, is based on the mass balance equation (Equation 1) while

$189 d V_{s y s} / d t$ represents the water storage in the lake. In the steady state, the water budget equation

190 allows the computation of the residual flux $\left(V_{R}\right)$ (Equation 3) which represents the amount of

191 freshwater exchanged between the Ichkeul Lake and the Bizerte Lagoon. The theoretical flux

$192\left(V_{R}\right)$ is foreseen as the flux which restores the equilibrium of the Lake at the steady-state

193 condition and could be either an outflow or inflow. The horizontal water exchange fluxes $V_{\text {in }}$ and

$194 V_{\text {out }}$ are hydrographically driven by advection entering and leaving the system, respectively. Their

195 difference is the residual flux.

196 The fluxes to the system are under several forms which are inflows from the rivers $\left(V_{Q}\right)$, direct

197 precipitation $\left(V_{P}\right)$, ground water $\left(V_{G}\right)$ and other sources $\left(V_{O}\right)$ not streaming on the ground such as

198 sewage and industrial waste. The out fluxes with respect to the Ichkeul Lake are under the form

199 of evaporation $\left(V_{E}\right)$. In the LOICZ, budget computation approach is based on the consideration of 
200 steady-state ( $V_{\text {sys }}$ and $V_{R}$ are constants). In the present study, the groundwater volume $\left(V_{G}\right)$ and

201 other volumes $\left(V_{O}\right)$ such as industrial and sewage waste are ignored. The difference between the

202 inputs and outputs to and from the lake are called $V_{Q^{*}}$ and is expressed by Equation 2.

$203 \frac{d V_{\text {sys }}}{d t}=V_{\text {in }}-V_{\text {out }}+V_{Q^{*}}$

$204 \quad V_{Q^{*}}=V_{Q}+V_{P}+V_{G}+V_{O}-V_{E}$

$205 \quad V_{R}=V_{\text {in }}-V_{\text {out }}=\frac{d V_{\text {sys }}}{d t}-V_{Q^{*}}$

206 In the steady state condition:

$207 \quad V_{R}=-V_{Q^{*}}=V_{E}-\left(V_{P}+V_{G}+V_{O}+V_{Q}\right)$

$208 \quad$ 2.4.2 Salt budget

209 The salt budget is estimated based on the amount of seawater exchanged between the system and

210 the ocean due to the influence of currents exchanging materials (mixing flux $V_{X}$ ). This flux does

211 not lead to significant changes in volume and is, therefore, not included in the water budget.

212 However, it is very important for nutrient flows as a mass of nutrient-rich system water is

213 replaced by an equal mass of nutrient-poor seawater. To quantify $V_{X}$, the salt budget which has a

214 conservative behavior can be used to estimate the mixing flux. Therefore, the salt flux not

215 considered by the salinities used to describe the freshwater, should be balanced by the mixing

216 flux $V x *\left(\mathrm{~S}_{\mathrm{ocn}}-\mathrm{S}_{\mathrm{sys}}\right)$; although in freshwater systems, the mixing flux tends to be null (Swaney et

217 al., 2011).

218 At steady state, the salt mixing flux $\left(V_{X}\right)$ is equal to the sum of the residual flux which is carrying

219 an amount of salinity $\left(S_{R}\right)$ described as the salinity of the residual flow (Equation 7), and the

220 freshwater inflow flux which is carrying an amount of salinity $\left(S_{Q} *\right)$ (Equation 9). The quantity 
221 of water exchanged through the residual and the mixing flux allows for the estimation of the

222 residence time of materials within the system (Equation 10).

$223 \frac{d\left(V_{\text {sys }} S_{\text {sys }}\right)}{d t}=V_{i n} S_{\text {ocn }}-V_{\text {out }} S_{s y s}+V_{Q^{*}} S_{Q^{*}}$

$224 \quad V_{R} S_{R}=V_{\text {in }} S_{\text {ocn }}-V_{\text {out }} S_{\text {sys }}$

$225 S_{R}=\frac{\left(S_{s y s}+S_{o c n}\right)}{2}$

$226 \frac{d\left(V_{s y s} S_{s y s}\right)}{d t}=V_{R} S_{R}+V_{Q^{*}} S_{Q^{*}}$

227 In the steady state condition:

228 Mixing Flux is,

$229 V_{X}\left(S_{o c n}-S_{s y s}\right)=-\left(V_{R} S_{R}+V_{Q^{*}} S_{Q^{*}}\right)$

230 Water renewal time is,

$231 \tau=\frac{V_{s y s}}{\left(V_{X}+\left|V_{R}\right|\right)}$

\section{$232 \quad$ 2.4.3 Non-Conservative variables budget}

233 Non-conservative materials (Y: DIP, DIN) owe their names to their non-conservativeness with

234 respect to water and salt and could be considered as reactive substances. They are called so since

235 their exchange fluxes through the lake are expected to leave an internal residual flux $(\Delta \mathrm{Y})$, due to

236 the internal processes occurring within the lake. The budgets for non-conservative materials

237 follow a salinity-based approach but consider the internal flux.

238 In the present work, the Dissolved Inorganic Nitrogen (DIN) is represented by the sum of nitrites

$239 \mathrm{NO}_{2}{ }^{-}$, nitrates $\mathrm{NO}_{3}^{-}$and ammonia $\mathrm{NH}_{4}{ }^{+}$while the Dissolved Inorganic Phosphorous (DIP) is

240 represented by phosphate $\mathrm{PO}_{4}{ }^{3-}$. LOICZ estimates the non-conservative materials DIN and DIP 
241 budgets at steady state by determining the residual flux of DIP and DIN namely $\Delta$ DIP and $\Delta$ DIN,

242 respectively (Equation 12).

$243 \mathrm{~V} * \frac{\mathrm{dY}}{\mathrm{dt}}+\mathrm{Y} * \frac{\mathrm{dV}}{\mathrm{dt}}=\sum\left(V_{\text {in }} * Y_{\text {in }}\right)-\sum\left(V_{\text {out }} * Y_{\text {out }}\right)+\Delta \mathrm{Y}$

244 At steady state:

$245 \Delta Y=-\left(V_{Q^{*}} Y_{Q^{*}}+V_{R} Y_{R}+V_{X}\left(Y_{s y s}-Y_{o c n}\right)\right)$

246 The value of $Y_{R}$ computed as the average between $Y_{\text {sys }}$ and $Y_{o c n}$ is given by Equation 13 .

$247 \quad Y_{R}=\frac{\left(Y_{s y s}+Y_{o c n}\right)}{2}$

\section{$248 \quad$ 2.4.4 Stoichiometric coefficients}

249 Mass-balance budgets are described to stoichiometrically link nutrient budgets through C:N:P

250 Redfield ratios (Redfield 1958). LOICZ principally uses those ratios to determine the excepted

$251 \Delta D I N$, Nfix-Denit and Net Ecosystem Metabolism (NEM). The expected $\triangle \mathrm{DIN}$ could be well 252 estimated through the observed $\Delta$ DIP (Gordon et al., 1996). The difference between the observed

253 and expected $\triangle \mathrm{DIN}$ (equation 14) is supposed to be equal to the difference of the quantity of $\mathrm{N}_{2}$ 254 produced through denitrification and that consumed through fixation (Seitzinger 1988). As for 255 the NEM, it is supposed to reflect the difference between the production and respiration (p-r) 256 within the lake, estimated (in Carbon) through the observed $\Delta \mathrm{DIP}$, exploring the Redfield ratio. 257 The P:C Redfield ratio is about (106:1) for phytoplankton (Redfield 1958) and (550:1) for sea 258 grass (Atkinson and Smith 1983).

$259 \quad$ Nfix-Denit $=\Delta(D I N)-\Delta(D I N)_{\text {exp }}$

$260 N E M=p-r=-\Delta(D I P) *(C: P)$ 
262 3.1 Physico-Chemical parameters

263 In the Ichkeul Lake, due to its shallow depth, the temperature is tightly linked to that of the

264 atmosphere. In the wet season, the water temperature was between $16.7^{\circ} \mathrm{C}$ in $\mathrm{S} 1$ and $19.3{ }^{\circ} \mathrm{C}$ in

265 S7 (Fig. 3A) where the water depth was relatively high. In the dry season, the Western and

266 Southern sectors were characterized by higher water temperatures of about $25{ }^{\circ} \mathrm{C}$ due to water

267 confinement and shallow depth (Fig. 3A').

268 Salinity of the Ichkeul Lake was high throughout the study period between 2016 and 2017. The

269 lowest value was about 30.7 recorded in winter then reaches 40.0 in the late summer (August). In

270 winter and summer, the salinity was likely to be homogenously distributed with an average of

$27131.17 \pm 0.3$ (Fig. 3B) and 39.91 \pm 0.2 (Fig. 3B'), respectively. In winter, lower values were

272 noticed at the outlet of the rivers carrying out freshwater. Meanwhile, in summer, they were

273 recorded by the side of the Tinja channel where the lagoon salinity was about 38.6, lower than the

274 other compartments of the lake.

275 Similar to salinity, the DO was almost homogenous during the year with average values of 10

276 mg. $.^{-1} \pm 0.3$ in winter (Fig. $3 \mathrm{C}$ ) and $6.8 \mathrm{mg} . \mathrm{l}^{-1} \pm 0.5$ in summer (Fig. 3C'). In winter, the highest

277 concentrations were in the South (S4 and S5) and Eastern side (S1) of the lake, whereas, in

278 summer, the highest concentrations were recorded in the Western side characterized by blooming

279 of Phanerogams.

280 Based on the overall field observations, the waters were turbid throughout the year essentially

281 due to the effect of meteorological conditions and also due to the morphology of the lake which

282 is characterized by very shallow water depth. Seasonally, the waters were more turbid in winter

283 during northwestern winds which force the sediment to re-suspend in the water column. 
284 However, in summer, the turbidity was relatively low in comparison to that observed in winter

285 due to the calm meteorological conditions. Spatially, the western sector was often characterized

286 by low turbidity due to the presence of phanerogams and water confinement.

\section{$287 \quad 3.2$ Chemical parameters}

\section{$288 \quad$ 3.2.1 Dissolved Phosphorus}

289 Overall, the Ichkeul Lake is characterized by low phosphorus levels during the sampling period.

290 The distribution of the Total Phosphorus (TP) in the lake was almost homogeneous during the

291 year with a high concentration observed in the north sector of the lake and a lower value in the 292 southern sector. In winter (Table 1), the total phosphorus varied between $3.6 \mu \mathrm{M}$ in the southern 293 sector where the Joumine River discharges and $8.1 \mu \mathrm{M}$ in the Northern sector where the Douimis

294 River discharges (Fig. 4A). In summer, we observed a similar distribution of the phosphorus in

295 the lake as in winter (Fig. 4A'), with an increase in values (Table 2) especially in the northern

296 sector where the TP reached $10.9 \mu \mathrm{M}$.

297 The Dissolved Inorganic Phosphorus (DIP) varied between $0.2 \mu \mathrm{M}$ and $1.3 \mu \mathrm{M}$ in winter (Table 298 1), while it varied between $0.1 \mu \mathrm{M}$ and $1.6 \mu \mathrm{M}$ in summer (Table 2). The highest concentration is 299 observed in the northern sector close to the Douimis River discharge in both winter (Fig. 4B) and 300 summer (Fig. 4B'), and the lowest values were observed in the southern sector of the lake.

\section{$301 \quad$ 3.2.2 Dissolved Nitrogen}

302 The distribution of the Total Nitrogen (TN) in the lake is characterized by a non-uniform spatial

303 distribution during the year. In winter (Table 1), a high concentration of about $27.5 \mu \mathrm{M}$ was

304 observed in the center of the lake and in the Tinja channel while the lowest value of $23.0 \mu \mathrm{M}$ was

305 observed in the western and in the North-eastern side (Fig. 4C). In summer (Table 2), a high 306 concentration of about $23.8 \mu \mathrm{M}$ was observed in the southern sector (Fig. 4C') where discharges 
307 of the Joumine River take place, whereas the lowest value of $14.3 \mu \mathrm{M}$ was observed in the

308 western sector and in the North-eastern side of the lake.

309 For the Dissolved Inorganic Nitrogen (DIN) (Fig. 4D) the level of concentrations is obviously

310 higher in winter than in summer (Fig. 4D'). In winter, the Eastern sector recorded the highest

311 concentration $(15.4 \mu \mathrm{M})$ while in summer the highest level was detected in the West-southern

312 side $(6.2 \mu \mathrm{M})$ where the discharges of the Joumine River take place.

\section{$313 \quad$ 3.2.3 Chlorophyll $a$}

314 The Chla concentration showed a clear contrast and variation between seasons. In winter, the

315 average concentration reached $8.5 \pm 3.3 \mu \mathrm{g} \cdot \mathrm{l}^{-1}$ (Table 1), with the highest concentrations observed

316 at S2 (Fig. 4E). In summer, the average concentration was relatively low at about $3.1 \pm 0.6 \mu \mathrm{g} .1 \mathrm{l}^{-}$

$317{ }^{1}$ (Table 2) in the Western sector (S3, S4) (Fig. 4E').

\section{$318 \quad 3.3$ Multivariate statistical analysis}

319 The PCA was performed for winter and summer separately to comprehend the correlation

320 between the sampling area, Chla, and chemical and physico-chemical parameters for each season,

321 and also to highlight the seasonal functioning (Fig. 5).

322 In winter (Fig. 5A), the two first components described $68 \%$ of the total variance. The first

323 component $(41,4 \%)$ tracked a combination of trophic related variables, phosphorus and

324 Chlorophyll $a$, opposed to dissolved oxygen, and discriminated the area close to the inlet (S1)

325 and the coastal area localized close to the mouth of the Douimis River (S2). The second

326 component (26.6\%) mainly discriminated the nitrogen and the temperature between the area close

327 to the inlet (S1) and the inner sector (S5) from one side and the southeast coast area (S3 and S4)

328 which captured the effect of Sejnene and Melah Rivers. 
329 In summer (Fig. 5A'), when the lake received waters from the lagoon, the first two components

330 accounted for $60.9 \%$ of the total variability. The first component (37.3\%) - dominated by the

331 combination of nitrogen, Chlorophyll $a$, and, with the opposite sign, phosphorous - discriminated

332 the inner and western coastal regions close to the Douimis River (S3, high Chla, high N, and low

333 P) from the eastern stations close to Joumine and Tine Rivers (S5, high $\mathrm{P}$, low $\mathrm{N}$, and Chla) and

334 the inlet (S1, high $\mathrm{P}$, low $\mathrm{N}$, and $\mathrm{Chl} a)$.The second component (23,6\%), however, described

335 mainly gradients in temperature and dissolved oxygen between areas south and close to the

336 Melah River (S4, high T, low DO) or Tine-Joumine system (S5) and northern stations close to the

337 inlet of Tinja Channel (S1, low T, and high DO).

\section{$338 \quad 3.4$ LOICZ Results}

\section{$339 \quad$ 3.4.1 Water and salt budget}

340 During the winter season (Fig. 6A), the Ichkeul Lake received a quantity of freshwater from the

341 six rivers $\left(\mathrm{V}_{\mathrm{Q}}=390.610^{3} \mathrm{~m}^{3} \cdot \mathrm{d}^{-1}\right)$ and a flux of direct precipitations $\left(\mathrm{V}_{\mathrm{P}}=381.710^{3} \mathrm{~m}^{3} \cdot \mathrm{d}^{-1}\right)$.

342 Meanwhile, evaporation was about $-234.010^{3} \mathrm{~m}^{3} \cdot \mathrm{d}^{-1}$. The water residual flow given as a result

343 from the LOICZ model was equal to $-538.210^{3} \mathrm{~m}^{3} \cdot \mathrm{d}^{-1}$. Its negative value indicates that water

344 leaves the Ichkeul Lake towards the Bizerte Lagoon. At steady state, the $V_{R}$ freshwater outflow

345 carried salt by advection outside of the lake with the boundary salinity $\mathrm{S}_{\mathrm{R}}$ being almost equal to

346 34.2. The advective salt delivery to the lagoon is given by the flux $V_{R} * S_{R}$ which was about -

$34718,406.410^{3} \mathrm{~m}^{3} \cdot \mathrm{d}^{-1}$, thus explaining the lower salinity in the lake (31.7) than the lagoon (37.2).

348 To remove the excess of salt in the latter, the water mixing flux $\mathrm{V}_{\mathrm{X}}$ was computed so that $\mathrm{V}_{\mathrm{x}}$

$349\left(\mathrm{~S}_{\mathrm{ocn}}-\mathrm{S}_{\mathrm{sys}}\right)$ was equal to $-\left(\mathrm{V}_{\mathrm{R}} \mathrm{S}_{\mathrm{R}}+\mathrm{V}_{\mathrm{Q}} * \mathrm{~S}_{\mathrm{Q}} *\right)$. In this case, at steady-state, the mixing flux entering the

350 lake from the lagoon was about 2,589.5 $10^{3} \mathrm{~m}^{3} \cdot \mathrm{d}^{-1}$. The residence time in winter was about 31 351 days. 
352 In summer (Fig. 6A'), the amount of freshwater flowing to the lake from precipitation $\left(\mathrm{V}_{\mathrm{P}}=15.1\right.$

$\left.35310^{3} \mathrm{~m}^{3} \cdot \mathrm{d}^{-1}\right)$ and rivers $\left(\mathrm{V}_{\mathrm{Q}}=15.410^{3} \mathrm{~m}^{3} \cdot \mathrm{d}^{-1}\right)$ remained low compared to the losses by evaporation

$354\left(V_{\mathrm{E}}=-131.910^{3} \mathrm{~m}^{3} \cdot \mathrm{d}^{-1}\right)$ inducing lagoon waters to enter the lake $\left(\mathrm{V}_{\mathrm{R}}=101.410^{3} \mathrm{~m}^{3} \cdot \mathrm{d}^{-1}\right)$ thereby

355 carrying salt to the lake which its salinity increased to 40.0 while that of the lagoon was about

356 38.6. To equilibrate the slight salt difference between the two systems $V_{R} S_{R}+V_{Q^{*}} S_{Q^{*}}$ and $V_{x}$

357 ( $\left.\mathrm{S}_{\text {ocn- }} \mathrm{S}_{\mathrm{sys}}\right)$ fluxes must be equal in opposite signs, $\mathrm{V}_{\mathrm{x}}$ had to be equal to $3,097.210^{3} \mathrm{~m}^{3} \cdot \mathrm{d}^{-1}$. In this

358 situation, the residence time in the system was about 10 days.

$359 \quad 3.4 .2$ Non-conservative materials budgets

360 DIP budget

361 During winter, the observed $\Delta \mathrm{DIP}$ value was about $618 \mathrm{~mol} \mathrm{P} \mathrm{d}^{-1}$ (Fig. 7A) while in summer it 362 was about 1,106 mol P d${ }^{-1}$ (Fig. 7A'). For winter and summer, the Ichkeul Lake acted as a source 363 of DIP.

364 DIN budget

365 LOICZ gives observed $\triangle \mathrm{DIN}$ from the processes involving nitrogen inside the Lake. In winter, 366 the $\Delta \mathrm{DIN}$ was positive at about $14,644.0 \mathrm{~mol} \mathrm{~N} \mathrm{~d}^{-1}$ (Fig. 7B), indicating that the lake acts as a

367 source of DIN. The expected DIN (based on the Redfield ratio) was about 9,888.0 mol N d${ }^{-1}$ for 368 phytoplankton and $18,540.0 \mathrm{~mol} \mathrm{~N} \mathrm{~d}^{-1}$ for seagrass. Therefore, the difference between $\mathrm{N}$-fixation 369 and denitrification was $4,756.0 \mathrm{~mol} \mathrm{~N} \mathrm{~d}^{-1}$ and $-3,896.0 \mathrm{~mol} \mathrm{~N} \mathrm{~d}^{-1}$ for phytoplankton and seagrass, 370 respectively.

371 In summer, the $\Delta \mathrm{DIN}$ was negative at about $-2,355.0 \mathrm{~mol} \mathrm{~N} \mathrm{~d}^{-1}$ (Fig. 7B'), indicating that the lake

372 is a sink of DIN. The expected DIN was $33,180.0 \mathrm{~mol} \mathrm{~N} \mathrm{~d}^{-1}$ for seagrass and $17,696.0 \mathrm{~mol} \mathrm{~N} \mathrm{~d}^{-1}$

373 for phytoplankton. Therefore, the difference between $\mathrm{N}$-fixation and denitrification was $-35,535.0$

$374 \mathrm{~mol} \mathrm{~N} \mathrm{~d}^{-1}$ and $-20,051.0 \mathrm{~mol} \mathrm{~N} \mathrm{~d}^{-1}$ for seagrass and phytoplankton, respectively. 
376 NEM is an indicator of the trophic metabolism within the Ichkeul Lake, being the difference

377 between the primary production and respiration. In winter, the NEM was about $-65,508.0$ and -

$378339,900.0 \mathrm{~mol} \mathrm{~N} \mathrm{~d}^{-1}$ for phytoplankton and seagrass, respectively, whereas in summer the NEM

379 was about $-117,236.0$ and $-608,300.0 \mathrm{~mol} \mathrm{~N} \mathrm{~d}^{-1}$ for phytoplankton and seagrass, respectively

380 (Table 3).

381 4. Discussion

382 It is evident from the literature and from recent studies that the hydraulic constructions that 383 started in the 90's have caused significant hydrological and salinity imbalance of the Ichekeul 384 Lake ecosystem. The Constructions of the six dams on the main rivers flowing into the lake, the 385 high evaporation rates, and the scarcity of precipitation have reduced the water level in the lake. 386 However, under the strain of climate change, the latter has been drastically reduced, resulting in 387 very high salinity and lower water depth. The campaign carried out in the frame of the present 388 study (2016-2017) has shown that the water depth varied between 0.37 in August and $1.3 \mathrm{~m}$ in 389 March (annual mean $=0.71 \mathrm{~m}$ ), whereas the salinity ranged from 27.7 in March to 40.0 in August 390 (annual mean =33.8). Other issues which impacted the water level in the lake were the deposit of 391 fine sediment on the Northeast sector and the locks installed in the Tinja channel. During this 392 year, the lack of freshwater inputs from precipitation and from the rivers coupled with high 393 evaporation rates has dropped the lake water levels to acute depths (Affouri and Sahraoui 2017).

394 The calculation performed by the LOICZ model showed the seasonal residual flux to be $-0.2510^{6}$ $395 \mathrm{~m}^{3}$. Consequently, the net water budget is about $68.4510^{6} \mathrm{~m}^{3}$ (average of 2016-2017), which is 396 obviously low compared to the average volume of about $90.0010^{6} \mathrm{~m}^{3}$ for the lake. This situation 397 has strongly affected the salinity which reached 40.0 in the summer season. 
398 Many of the world largest lakes, including Lake Victoria (Vanderkelen et al. 2018) and lake Chad

399 (Coe and Foley 2001, Gao et al. 2011) in sub-Saharan Africa, the Caspian Sea at the Europe-Asia 400 boundary (Prange et al. 2020), the Dead Sea in the Middle-East (Glausiusz, 2010), the Great 401 Lakes in USA (Gronewold and Stow 2014), and Poyang Lake in China (Mei et al. 2015) have 402 seen a significant decrease in their water levels. Shrinkage or even a complete disappearance of 403 lakes such as the Aral Sea in Central Asia (Micklin 2007) may be attributed to damming and 404 irrigation canals as well as to the mismanagement of their associated wetland ecosystems (Feng 405 et al. 2016). In spite of their reduced cover, lakes are globally important ecosystems that have for 406 too long been ignored in the estimations of global ecosystem processes, notably the material 407 processing in small lakes (Downing et al. 2006). In addition to the anthropogenic constructions 408 and mismanagement, climate change has been shown to affect the water level and/or water 409 hydrology in several large to small lakes, from the highest latitudes to the tropics including 410 coastal lakes and wetlands (Awange et al. 2008, Carroll et al. 2011). The Ichkeul Lake, at the 411 heart of the coastal wetland ecosystem and as a small freshwater body, has been shown in our 412 study to also be dramatically impacted by the damming upstream and the control of water 413 exchange with the adjacent lagoon and sea via the construction of locks which led to deceased 414 water levels, fluxes, and high salinity. Such mismanagement of water input and sediment deposits 415 compounded by climate change would add further multiple stressors to the lake and associated 416 ecosystem in the future. Indeed, it has been recently reported that climate change may increase 417 the vulnerability of wetlands in the Mediterranean. The cumulative evaporation in the region far 418 exceeds the cumulative precipitation leading to negative water balances that are enhanced by 419 mismanagement of water resources and thereby lead to further water scarcity in one of the most 420 impacted Ecoregions. Under climate projections scenarios RCP 4.5 and RCP 8.5, more than 70\% 
421 of the wetlands in North Africa will be affected by hydrological stress, unless proper strategies at

422 the regional, national and local scales are adopted (Lefebre et al. 2019).

423 The global climatic conditions as well as human activities have affected not only the hydrological

424 conditions, but also the water quality of the lake. As an example, the dissolved oxygen

425 measurements have shown that waters are usually close to being saturated in dissolved oxygen

426 (11.3 $\left.\mathrm{mg} \mathrm{l}^{-1}\right)$. These high values could be linked to phytoplankton and seagrass photosynthetic

427 activities (Casagranda and Boudoureaques 2009). However, the very low concentrations,

428 observed in the southwest sector may be due to the presence of organic waste from the Joumine

429 River that receives wastewater discharges from the Mateur town (Touaylia et al. 2016). As for 430 water quality, calculations performed using TRIX index (Béjaoui et al. 2016, 2018) have revealed

431 very poor water quality $(5.61<$ TRIX $<8.46)$. The residence time reaching 1 month $(31$ days in 432 winter) may contribute to the development of phytoplankton and macroalgae blooms, therefore 433 reducing water quality and generating episodes of eutrophication in the lake. The Ichkeul Lake 434 being a Biosphere Reserve and a RAMSAR Site, does not permit the use of biomanipulation 435 measures to control eutrophication, and, therefore, the best procedures to control localized anoxia 436 and eutrophication would be an improved management of the water fluxes and the organic waste 437 from towns and cities bordering the Lake (Chislock et al. 2013). Indeed, several lakes and water 438 bodies that have seen increased eutrophication and anoxia have witnessed a drastic rise and 439 increase in phytoplankton and macroalgal blooms with the recent increase in climate change 440 effects. In many cases, the blooming species were toxic to food webs and humans and could pose 441 a real threat to the large diversity of the waterfowls of the Lake Ichkeul under the projected 442 climate change scenarios for the Mediterranean region (Paerl and Hisman 2009; Paerl et al. 2009; 443 O’Neil et al. 2012). 
444 The nutrient budgets in the lake are also the direct consequence of the terrigenous waters from

445 rivers which are enriched by chemical components coming from the agricultural activities and 446 urban waste of the Mateur town.

447 The multivariate analysis suggests that the trophic status in the lake is phosphorous-dependent in 448 winter and nitrogen-dependent in summer. In winter, the gradients between the areas close to the 449 inlet and the coastal area near the mouth of the Douimis River, captured by the first two principal 450 components of the PCA, suggest that the hydrodynamic pattern driven by the influence of the 451 lagoon from one side and the effect of Douimis River from the other side has a major influence in 452 shaping the lagoon biogeochemical functioning. Indeed, the observed values of the dissolved 453 oxygen in the area around the inlet were high $(10 \mathrm{mg} / \mathrm{l})$, likely a hydrodynamic effect between the 454 Lake and the Lagoon. Similar results were observed for the phosphorous $(1.3 \mu \mathrm{M})$ and 455 Chlorophyll $a(15 \mu \mathrm{g} / \mathrm{l})$ which showed the highest values around the mouth of the Douimis River. 456 In general, in this season, the ordination of the station indicates a high heterogeneity among all 457 stations and variables, with a less clear a posteriori geographical interpretation of results, in 458 respect to summer. Salinity has a more important ordination role in summer, possibly as a result 459 of the rivers-lagoon gradients, and the pattern of nitrogen and phosphorus shows some 460 dissimilarity, possibly related to the presence of different sources. The temperature gradient also 461 differed from the summer one. In summer, the lake functioning was characterized by the 462 superposition of a major gradient between the inlet and the Douimis River tracked by the trophic 463 status variables Chlorophyll $a$ and phosphorous and by the dissolved oxygen and also possibly 464 explained by the hydrodynamic functioning. In the summer season, the lake functioning is driven 465 by the influence of the inlets and the Melah, Joumine and Tine Rivers.

466 The application of the LOICZ model allowed for more detailed nutrient budgets in the lake. 467 During the wet season, the value of Dissolved Inorganic Phosphorus ( $\Delta \mathrm{DIP})$ calculated by the 
model is positively close to zero, suggesting that the Ichkeul Lake acts as a source of DIP. Based

469 on the Redfield approximation, the expected DIN for phytoplankton and seagrass was about $4709,888.0$ and $18,540.0 \mathrm{~mol} \mathrm{~N} \mathrm{~d}^{-1}$, respectively, indicating that the Ichkeul Lake is a source of DIN 471 in the wet season. The accumulation of nitrogen may be due to the decomposition of 472 phanerogams and the release of organic matter from sediments (Casagranda and Boudoureaques 473 2009). The difference between the DIN measured in the lake and the DIN expected by the model 474 is assumed to be the gaseous form of nitrogen in the lake as $\mathrm{N}_{2}$ gas. The Di-Nitrogen is supposed 475 to be equal to the difference between the $\mathrm{N}$-fixation and Denitrification. The Nitrogen fixation 476 and denitrification are likely to be important pathways for non-conservative nitrogen flux, in 477 warm coastal ecosystems (Saunders and Kaffl 2001, Swaney et al. 2011); the nitrogen being 478 balanced by the denitrification and fixation processes. In the winter season, the Nfix-Denit is 479 about $4,756.0$ and $-3,896.0 \mathrm{~mol} \mathrm{~N} \mathrm{~d}^{-1}$ for phytoplankton and seagrass, respectively, suggesting 480 that the $\mathrm{N}_{2}$ fixation is more important than the denitrification for phytoplankton; however, for 481 seagrass the Nfix-Denit is negative suggesting that the nitrogen fixation is relatively hard and the 482 denitrification is a very dominant process due to several environmental factors. This situation 483 also demonstrates that the ecosystem is suffering from pollution and deoxygenation. The Net 484 Ecosystem Metabolism (NEM = production-respiration) determined through the Redfield molar 485 ratio between the phosphorus and the Carbone in the ecosystem is about -65508.0 and $-339,900.0$ 486 mol $\mathrm{N} \mathrm{d}^{-1}$ for phytoplankton and seagrass, respectively. These negative values suggest that 487 respiration is prevailing in comparison to production, and is attributed to the environmental 488 conditions within the ecosystem. In this situation, the ecosystem is qualified as a confined 489 ecosystem, whereas the metabolism of the Lake is considered as heterotrophic.

490 Unlike the wet season, in the summer, the lake has shown different characteristics. The $\Delta \mathrm{DIP}$ is $491 \quad 1,106.0 \mathrm{~mol} \mathrm{~N} \mathrm{~d}^{-1}$, also positive close to zero, suggesting that the lake acts as a source of DIP. 
492 The corresponding expected $\triangle \mathrm{DIN}$ is about $17,696.0$ and $33,180.0$ mol N d $\mathrm{d}^{-1}$ for phytoplankton

493 and seagrass, respectively, indicating that the lake is a source of DIN. The difference between the

494 observed and the expected $\triangle \mathrm{DIN}$, based on the LOICZ model, could be attributed to the $\mathrm{N}_{2}$

495 amount generated by the denitrification and/or anammox, the process of ammonium and nitrite

496 conversion into $\mathrm{N}_{2}$ gas by chemoautotrophic bacteria in anoxic conditions (Davidson and

497 Seitzinger 2006). For Ichkeul Lake the flux of Nfix-Denit is usually negative at about $-20,051.0$

498 for phytoplankton and $-35,535.0 \mathrm{~mol} \mathrm{~N} \mathrm{~d}^{-1}$ for seagrass, respectively, indicating that the

499 denitrification/anammox processes are dominant in the Lake.



501 phytoplankton and seagrass, respectively, indicating that respiration exceeds production and also

502 suggesting that an important amount of nitrogen gases diffuses to the atmosphere through the

503 interface atmosphere-Lake, either as $\mathrm{N}_{2}$ or as $\mathrm{N}_{2} \mathrm{O}$. Although the amount of gaseous $\mathrm{N}$ that

504 escapes to the atmosphere from the lake was not quantified in the present study, a recent study

505 examining nitrogen processing and patterns in 34 lakes of the Midwest of the USA found that all

506 lakes had a net loss of $\mathrm{N}_{2}$ (Loeks-Johnson and Cotner 2020). Comparable seasonal differences

507 reported in our study have also been found in the Midwest lakes, with higher gaseous nitrogen

508 escape advanced by denitrification associated with anoxic conditions (Reddy et al. 1989). In

509 addition, increased temperature from climate change, as it is the case for North-Africa, increases

510 the production of $\mathrm{N}_{2}$ via the enhancement of the denitrification and/or anammox processes

511 (Adrian et al. 2009). Most studies on the supersaturation of lakes in $\mathrm{N}_{2}$ have shown that nitrogen

512 escapes to the atmosphere as $\mathrm{N}_{2}$, yet eutrophication likely increases its escape to the atmosphere

513 in its $\mathrm{N}_{2} \mathrm{O}$ from, thereby contributing to the greenhouse gas loading of the atmosphere; this is

514 critical since, $\mathrm{N}_{2} \mathrm{O}$ is 300 times more potent that $\mathrm{CO}_{2}$ (Seo and De Laune 2010, Montzka et al.

515 2011). The recent development of climate change and increased human activities, notably the 
516 excessive use of agricultural fertilizers, warrant further research into the transfer of nitrogen to

517 the atmosphere from wetlands and coastal wetland ecosystems.

\section{5. Conclusion}

519 The most significant aspects of the functioning of the Lake Ichkeul ecosystem revealed through

520 the numerical and experimental approach used in this study concern the hydrological, the

521 biogeochemical and the metabolic functioning of the Lake (Supporting Information Fig. S1).

522 Concerning the hydrological functioning, in winter the waters leave the Lake towards the Bizerte

523 Lagoon; however, the lake gets filled from the Lagoon in summer, significantly increasing its

524 salinity. This situation is becoming critical for the biotope with the decrease of the freshwater

525 inputs from rivers and the bad management of locks installed on the Tinja Channel. Concerning

526 the biogeochemical functioning, the lake acts as a source of phosphorus and nitrogen during the

527 wet season; however, it acts as a sink of nitrogen and as a source of phosphorus during the dry

528 season. The internal processes of the trophic web seem to be marked by the high denitrification

529 and/or anammox and low production; this suggests that a considerable amount of $\mathrm{N}_{2}$, and

530 potentially some amount of $\mathrm{N}_{2} \mathrm{O}$, escapes toward the atmosphere. The study also indicates that

531 the denitrification/anammox processes are strongly linked to environmental conditions. Pollution

532 is among the main inhibiting factors for not only water quality, but also for the net ecosystem

533 metabolism which is marked by respiration. For the management of the Ichkeul Lake wetland,

534 the key to success resides in improved water management and depollution.

\section{Acknowledgments}

536 This study was carried out within the framework of the MODAPEX project (National Research

537 Project, INSTM, University of Carthage, Tunisia). A part of this work has been supported by an

538 OGS-ICTP TRIL Fellowship, and the IMAS-Ichkeul project (Subaward Number: 2000011045) 
539 funded by the United States Agency for International Development - USAID, USA (AID-OAA-

540 A-11-00012) and managed by the National Academies of Sciences, Engineering and Medicine -

541 NASEM. Preliminary data for this research was collected as part of the master thesis of Mr.

542 Tarek Abdallah.

543 


\section{References}

545 Abdallah T, Béjaoui B, Ben M'Barek N, Alouani B, Arif A, Harzallah A (2017) Modeling of

546 water levels, water, heat and salt exchanges between Ichkeul Lake and Bizerte Lagoon:

547 Hydrodynamical interaction between two coastal water bodies, The $1^{\text {st }}$ Atlas Georessources

548 International Congress, 20-22 March 2017, Hammamet, Tunisia.

549 Adrian A, O’Reilly CM, Zagarese H, Baines SB et al (2009) Lakes as sentinels of climate

550 change. Limnol. Oceanogr. 54, 2283-2297. https://doi.org/10.4319/lo.2009.54.6_part_2.2283

551 Affouri H, Sahraoui O (2017) The sedimentary organic matter from a Lake Ichkeul core (far 552 northern Tunisia): Rock-Eval and biomarker approach. J Afr Earth Sci 553 https://doi.org/10.1016/j.jafrearsci.2017.01.017

554 Anagnostou E, Gianni A, Zacharias I (2017) Ecological modeling and eutrophication-A review.

555 Nat Resource Model https://doi.org/10.1111/nrm.12130

556 APHA (American Public Health Association) (1992) Standard Methods for the Examination of

557 Water and Wastewater. American Public Health Association, Washington DC, 18th Edition.

558 Atkinson MJ, Smith SV (1983) C:N:P ratios of benthic marine plants. Limnol Oceanogr 559 https://doi.org/10.4319/lo.1983.28.3.0568

560 Awange JL, Sharifi MA, Ogonda G, Ickert J, Grafarend EW, Omulo MA (2008) The Falling

561 Lake Victoria Water Level: GRACE, TRIMM and CHAMP Satellite Analysis of the Lake Basin.

562 Water Resour Manage https://doi.org/10.1007/s11269-007-9191-y 
563 Ayache F, Thompson JR, Flower RJ, Boujarra A, Rouatbi F, Makina H (2009) Environmental

564 characteristics landscape history and pressures on three coastal lagoons in the Southern

565 Mediterranean Region: Merja Zerga (Morocco) Ghar El Melh (Tunisia) and Lake Manzala

566 (Egypt). Hydrobiologia https://doi.org/10.1007/s10750-008-9676-6

567 Baird M, Middleton J (2004) On Relating Physical Limits to the Carbon: Nitrogen Ratio of

568 Unicellular Algae and Benthic Plants. J Mar Sys https://doi.org/10.1016/j.jmarsys.2003.10.007

569 Basset A, Elliott M, West RJ, Wilson JG (2013) Estuarine and lagoon biodiversity and their

570 natural goods and services. Estuar Coast Shelf Sci https://doi.org/10.1016/j.ecss.2013.05.018

571 Beck MW, Heck KL, Able KW (2001) The Identification, Conservation, and Management of

572 Estuarine and Marine Nurseries for Fish and Invertebrates: A better understanding of the habitats

573 that serve as nurseries for marine species and the factors that create site-specific variability in

574 nursery quality will improve conservation and management of these areas. BioScience

575 https://doi.org/10.1641/0006-3568(2001)051[0633:TICAMO]2.0.CO;2

576 Béjaoui B, Armi Z, Ottaviani E, Barelli E, Gargouri-Ellouz E, Chérif R, Aleya L (2016) Random

577 Forest model and TRIX used in combination to assess and diagnose the trophic status of Bizerte

578 Lagoon, southern Mediterranean. Ecol Indic https://doi.org/10.1016/j.ecolind.2016.07.010

579 Béjaoui B, Ottaviani, E, Barelli E, Ziadi B, Dhib A, Lavoie M, Gianluca C, Turki S, Solidoro C,

580 Aleya L (2018) Machine learning predictions of trophic status indicators and plankton dynamic

581 in coastal lagoons. Ecol Indic https://doi.org/10.1016/j.ecolind.2018.08.041 
582 Béjaoui B, Solidoro C, Harzallah A, Chevalier C, Chapelle A, Zaaboub N, Aleya L (2017) 3D

583 Modeling of Phytoplankton Seasonal Variation and Nutrient Budget in a Southern Mediterranean

584 Lagoon. Mar Poll Bull https://doi.org/10.1016/j.marpolbul.2016.11.001.

585 Ben M'Barek N, Slim-Shimi N (2002) Evolution des paramètres physico-chimiques des eaux du

586 lac Ichkeul après la réalisation des aménagements hydrauliques (Tunisie). Proceedings of

587 International Symposium and Workshop on Environmental Pollution Control and Waste

588 Management, Tunis EPCOWM'2002, 20:27. https://docplayer.fr/42292743-Evolution-des-

589 parmetres-physico-chimiques-des-eaux-du-lac-ichkeul-apres-la-realisation-des-amenagements-

590 hydrauliques-tunisie.html.

591 BirdLife International (2021) Important Bird Area Factsheet: Ichkeul, Tunisia. Available at:

592 http://datazone.birdlife.org/site/factsheet/ichkeul-iba-tunisia/text

593 Brik B, Aydi A, Riahi C, Sdiri A, Regaya K (2018) Contamination levels and vertical distribution

594 of trace metals with application of geochemical indices in the sediment cores of the Bizerte 595 Lagoon-Ichkeul lake complex in northeastern Tunisia. Arab J Geosci 596 https://doi.org/10.1007/s12517-017-3382-5

597 Burgis MJ, Symoens JJ (1987) African wetlands and shallow water bodies- Zones humides et 598 lacs peu profonds d'Afrique. Directory Repertoire. Éditions de l'ORSTOM-Institut Français de 599 Recherche Scientifique pour le développement en coopération, Collection Travaux et Documents $600 \quad \mathrm{n}^{\circ} 211,1-56$. 
601 Carroll ML, Townshend RHG, DiMiceli CM, Loboda T, Sohlberg RA (2011) Shrinkage lakes of

602 the Artic: Spatial relationships and trajectory of change. Geophys Res Lett 603 https://doi.org/10.1029/2011GL049427

604 Casagranda C, Boudouresque CF (2009) A first quantification of the overall biomass, from 605 phytoplankton to birds, of a Mediterranean brackish lagoon: revisiting the ecosystem of Lake 606 Ichkeul (Tunisia). Hydrobiologia https://doi.org/10.1007/s10750-009-9986-3

607 Seo CD, DeLaune RD (2010) Fungal and bacterial mediated denitrification in wetlands: 608 Influence of sediment redox condition. Water Res https://doi.org/10.1016/j.watres.2010.01.006

609 Chislock MF, Doster E, Zitomer RA, Wilson AE (2013). Eutrophication: Causes, Consequences, 610 and Controls in Aquatic Ecosystems. Nature Education Knowledge 4(4):10.

611 Coe MT, Foley JA (2001) Human and natural impacts on the water resources of the Lake Chad 612 basin. J Geophys Res Atmos. https://doi.org/10.1029/2000JD900587

613 Costanza R, de Groot R, Sutton P, van der Ploeg S, Anderson SJ, Kubiszewski I, Farber S, 614 Turner RK (2014) Changes in the global value of ecosystem services. Global Environ Change 615 http://dx.doi.org/10.1016/j.gloenvcha.2014.04.002

616 Daoud-Bouattour A, Muller SD, Ferchichi-Ben Jamaa H et al (2011) Conservation of 617 Mediterranean wetlands: Interest of historical approach. $\mathrm{C} \quad \mathrm{R}$ Biol 618 https://doi.org/10.1016/j.crvi.2011.07.006.

619 Davidson EA, Seitzinger S (2006) The enigma of progress in denitrification research. Ecol Appl 620 https://doi.org/10.1890/1051-0761(2006)016[2057:TEOPID]2.0.CO2 
621 Derouiche E (2016) Analyse de la migration catadrome de l'anguille européenne Anguilla 622 anguilla (L. 1758) dans les lagunes septentrionales de Tunisie: caractéristiques et état de santé 623 des individus, quantification du phénomène. https://www.oceandocs.org/handle/1834/10379.

624 Downing JA, Prairie YT, Cole JJ et al (2006) The global abundance and size distribution of 625 lakes, ponds, and impoundments. Limnol Oceanogr https://doi.org/10.4319/lo.2006.51.5.2388

626 Elmberg J, Nummi P, Pöysä H, Sjöberg K (1994) Relationships between species number, lake 627 size and resource diversity in assemblages of breeding waterfowls J Biogeogr 21:7 -84

628 Euliss NH, Smith LM, Wilcox DA, Browne BA (2008) Lining ecosystem processes with wetland 629 management goals: Chartering a course for a sustainable future. Wetlands 630 https://doi.org/10.1672/07-154.1

631 Feng L, Han X, Hu C, Chen X (2016) Four decades of wetland changes of the largest freshwater 632 lake in China: Possible linkage to the Three Gorges Dam?. Remote Sens. Environ. 179: 43-55. 633 https://doi.org/10.1016/j.rse.2016.01.011

634 Ganju, N.K., Brush, M.J., Rashleigh, B., Aretxabaleta, A.L., Del Barrio, P., Grear, J.S., Vaudrey, 635 J.M.P., 2016. Progress and challenges in coupled hydrodynamic-ecological estuarine modeling. 636 Estuaries and Coasts https://doi.org/10.1007/s12237-015-0011-y

637 Gibbs JP (1993) Importance of small wetlands for the persistence of local populations of 638 wetland-associated animals. Wetlands https://doi.org/10.1007/BF03160862

639 Gibbs JP (2000) Wetland loss and biodiversity conservation. Conserv Biol 640 https://doi.org/10.1046/j.1523-1739.2000.98608.x 
641 Gao H, Bohn TJ, Podest E, McDonald KC, Lettenmaier DP (2011) On the causes of the shrinking 642 of Lake Chad. Environ Res Lett https://doi.org/10.1088/1748-9326/6/3/034021

643 Giordani G, Viaroli P, Swaney DP, Murray CN, Zaldívar JM, Marshall Crossland JI (2005)

644 Nutrient fluxes in transitional zones of the Italian coast. LOICZ Reports \& Studies No. 28, ii+157

645 pages, LOICZ, Texel, the Netherlands.

646 Glausiusz J (2010) Environmental Science: New life for the Dea Sea?. Nature 647 https://doi.org/10.1038/4641118a

648 Gordon DC, Boudreau PR, Mann KH, Ong JE, Silvert WL, Smith SV, Wattayarong G (1996)

649 LOICZ biogeochemical modelling guidelines, LOICZ Rep \& Stud 5:1-96. 650 https://www.ferrybox.eu/imperia/md/content/loicz/print/rsreports/report5.pdf

651 Gronewold AD, Stow CA (2014) Water Loss from the Great Lakes. Science 652 https://doi.org/10.1126/science. 1249978

653 Hamdi N, Touihri M, Charfi F (2012) Diagnostic Écologique du Parc National Ichkeul (Tunisie) 654 après la construction des barrages : cas des oiseaux d'eau. Rev Ecol 67:41-62.

655 Hassan MA, Klein M (2002) Fluvial adjustement of the Lower Jordan River to a drop in the Dea 656 Sea Level. Geomorphology https://doi.org/10.1016/S0169-555X(01)00187-8

657 Holmroos H, Horppila J, Niemistö J, Nurminen L, Hietanen S (2015) Dynamics of dissolved 658 nutrients among different macrophyte stands in a shallow lake. Limnology 659 https://doi.org/10.1007/s10201-014-0438-z 
$660 \mathrm{Hu}$ W (2016) A review of the models for Lake Taihu and their application in lake environmental 661 management. Ecol Modell https://doi.org/10.1016/j.ecolmodel.2015.07.028.

662 Hollis GE, Agnew CT, Battarbee W et al (1986) Modeling and management of the internationally 663 important wetland at Garaet Ichkeul Tunisia, Tunisia. Int. Waterfowl Res Bur 4. Spec Publ, 664 Slimbridge, pp 1-121

665 Hollis GE, Larson JS, Maltby E, Stewart RE, Dugan PJ (1987) Wise Use of Wetlands, 666 Proceedings of the Third Meeting of the Conference of the Contracting Parties to the Convention 667 on Wetlands of International Importance especially as Waterfowl Habitat Regina, IUCN/IWRB.

668 INM (2017) Données climatiques de la région de Bizerte. Institut National de Météorologie, 669 Tunis, Tunisie.

670 Junk WJ, An S, Finlayson CM, Gopal B, Květ J, Mitchell SA, Mitsch WJ, Robarts RD (2013)

671 Current state of knowledge regarding the world's wetlands and their future under global climate 672 change: a synthesis. Aquat Sci. https://doi.org/10.1007/s00027-012-0278-z

673 Kingsford RT, Basset A, Jackson L (2016) Wetlands: conservation's poor cousins. Aquat 674 Conserv. https://doi.org/10.1002/aqc.2709

675 Kitsiou D, Karydis M (2011) Coastal marine eutrophication assessment: A review on data 676 analysis. Environ Int. https://doi.org/10.1016/j.envint.2011.02.004

677 Kremer HH, LeTissier MDA, Burbridge PR, Talaue-McManus L, Rabalais NN, Parslow J, 678 Crossland CJ, Young B (2005) Land-ocean interactions in the coastal zone: science plan and 679 implementation strategy, IGBP Report 51, IHDP Report 18, International Geosphere-Biosphere 680 Programme. 
681 Lefebre G, Redmond L, Germain C, Palazzi E, Terzago S, Willm L, Poulin B (2019) Predicting 682 the vulnerability of seasonally-flooded wetlands to climate change across the Mediterranean 683 Basin. Sci Total Environ. https://doi.org/10.1016/j.scitotenv.2019.07.263

684 Loeks-Johson BM, Cotner JB (2020) Upper Midwest lakes are supersaturated with N2. PNAS 685 https://doi.org/10.1073/pnas.1921689117

686 Lorenzen CJ (1967) Determination of chlorophyll and pheopigments by spectrophotometric 687 equations. Limnol Oceanogr. https://doi.org/10.4319/lo.1967.12.2.0343

688 Macreadie PJ, Anton A, Raven JA et al (2019) The future of Blue Carbon. Nat Commun. 689 https://doi.org/10.1038/s41467-019-11693-w-11693-w

690 Mei X, Dai Z, Du J, Chen J (2015) Linkage between Three Gorges Dam impacts and the 691 dramatic recessions in China's largest freshwater lake, Poyang Lake. Sci Rep. 692 https://doi.org/10.1038/srep18197

693 Micklin P (2007) The Aral Sea Disaster. Ann. Rev. Earth Plan Sci. 694 https://doi.org/10.1146/annurev.earth.35.031306.14012

695 Mitsch WJ, Gosselink JG (2015) Wetlands, 5th edition. New jersey, Wiley.

696 Montzka SA, Dlugokencky IJ, Butler JH (2011) Non-CO2 greenhouse gases and climate change.

697 Nature https://doi.org/10.1038/nature10322

698 Newton A, Icely J, Cristina SC et al (2014) An Overview of Ecological Status Vulnerability and 699 Future Perspectives of European Large Shallow Semi-Enclosed Coastal Systems Lagoons and 700 Transitional Waters. Estuar Coast Shelf Sci. https://doi.org/10.1016/j.ecss.2013.05.023 
701 Newton A, Brito AC, Icely JD et al (2018) Assessing Quantifying and Valuing the Ecosystem

702 Services of Coastal Lagoons. J. Nat. Conserv. 44: 50-65,

703 https://doi.org/10.1016/j.jnc.2018.02.009

704 Newton A, Icely J, cristina S et al (2020) Anthropogenic Pressures on Coastal Wetlands. Front

705 Ecol Evol. https://doi.org/10.3389/fevo.2020.00144

706 O’Neil JM, Davis TM, Burford MA, Gobler CJ (2012) The rise of harmful cyanobacteria

707 blooms: The potential roles of eutrophication and climate change. Harmful Algae

708 https://doi.org/10.1016/j.hal.2011.10.027

709 Ouni H, Sousa MC, Ribeiro AS, Pinheiro J, Ben M'Barek N, Tarhouni J, Tlatli-Hariga N, Dias

710 JM (2020) Numerical modeling of hydrodynamic circulation in Ichkeul Lake-Tunisia, Energy

711 Rep. 6: 208-213. https://doi.org/10.1016/j.egyr.2019.08.044

712 Parsons, T.R., Y. Maita, and C.M. Lalli. 1984. A manual of chemical and biological methods for 713 seawater analysis. Mar. Ecol. Progr. Ser. 199: 43-53.

714 Paerl HW, Huisman J (2009) Climate change: a catalyste for global expansion of harmful

715 cyanobacteria blooms. Environ Microb Rep. https://doi.org/10.1111/j.1758-2229.2008.00004.x

716 Paerl HW, Nathan SH, Calandrino ES (2011) Controlling harmful cyanobacteria blooms in a

717 world experiencing anthropogenic and climatic-induced change. Sci Total Environ. 718 https://doi.org/10.1016/j.scitotenv.2011.02.001

719 Prange, M., T. Wilke, and F.P. Wesselingh. 2020. The other side of sea level change. Commun.

720 Earth Environ. 1: 69, https://doi.org/10.1038/s43247-020-00075-6 
721 Ramdani M, Flower RJ, Elkhiati N, Kraïem MN, Fathi AA, Birks HH, Patrick ST (2001) North

722 African wetland lakes: characterization of nine sites included in the CASSARINA Project. Aquat

723 Ecol. https://doi.org/10.1023/A:1011957324901

724 RAMSAR 2009. Convention and Wetlands International. Information Sheet on Ramsar Wetlands

725 Tunisia Ichkeul, Ramsar Sites Information Service.

726 RAMSAR 2010. Wise use of wetlands, Ramsar Handbooks, 4th edition.

727 Reddy KR, Patrick WH, Lindau CW (1989) Nitrification-denitrification at the plant root

728 sediment interface in Wetlands. Limnol Oceanogr. https://doi.org/10.4319/lo.1989.34.6.1004

729 Redfield AC (1958) The Biological Control of Chemical Factors in the Environment. American

730 Scientist.

731 Rodier J, Bazin C, Broutin JP, Chambon P, Champsur H, Rodi L (1996) L'analyse de l'eau, Eaux

732 naturelles, eaux résiduaires, eau de mer, Dunod Paris.

733 Saunders DL, Kaffl J (2001) Denitrification rates in the sediments of Lake Memphremagog,

734 Canda-USA. Water Res. https://doi.org/10.1016/S0043-1354(00)00479-6

735 Seitzinger SP (1988) Denitrification in Freshwater and Coastal Marine Ecosystems: Ecological

736 and Geochemical Significance. Limnol Oceanogr. https://doi.org/10.4319/lo.1988.33.4part2.0702

737 Seo CD, DeLaune RD (2010) Fungal and bacterial mediated denitrification in wetlands:

738 Influence of sediment redox condition. Water Res. https://doi.org/10.1016/j.watres.2010.01.006 
739 Shaiek M, Fassatoui C, Romdhane MS (2016) Past and present fish species recorded in the

740 estuarine Lake Ichkeul, northern Tunisia. Afr J Aquat Sci.

741 http://dx.doi.org/10.2989/16085914.2016.1153453

742 Strobl R, Zaldivar CJ, Somma F, Stips A, Garcia GE (2009) Application of the LOICZ

743 Methodology to the Mediterranean Sea, OPOCE, 1-41.

744 https://ec.europa.eu/jrc/en/publication/eur-scientific-and-technical-research-reports/application-

745 loicz-methodology-mediterranean-sea

746 Swaney DP, Smith SV, Wulff F (2011) The LOICZ Biogeochemical Modeling Protocol and its

747 Application to Estuarine Ecosystems. In: Bauer JE, Bianchi TS (Eds), Teratise on Estuarine and

748 Coastal Ecosystem Science, Academic Press, Elsevier, 136-159, https://doi.org/10.1016/B978-0-

$749 \quad 12-374711-2.00907-4$

750 Tamisier, A., O. Dehorter, A. Defosse, F. Poydenot, V. Gravez, and C.F. Boudouresque. 2001.

751 Modelling Aquatic Ecosystems: Benefits, Costs and Risks, for A Field Biologist. Ichkeul Lake,

752 Tunisia, A case study, p. 185-203. In F.A. Comin, J.A. Herrera, and J Ramirez [eds] Limnology

753 and Aquatic birds, Monitoring, modeling and management. Universidad de yucatán.

754 Touaylia S, Ghannem S, Toumi H, Béjaoui M, Garrido J (2016) Assessment of heavy metals

755 status in northern Tunisia using contamination indices: Case of the Ichkeul steams system,

756 IRJPEH. https://doi.org/10.15739/irjpeh.16.027

757 Turner RK, van den Bergh CJM, Södeeqvist T, Barendregt A, van der Straaten J, Maltby E, van

758 Ierland EC (2000) Ecological-economic analysis of wetlands: scientific integration for

759 management and policy. Ecol Econ. https://doi.org/10.1016/S0921-8009(00)00164-6 
760 UNESCO 2009a. Biosphere Reserve Information Tunisia Ichkeul, UNESCO-MAB Biosphere

761 Reserves Directory.

762 UNESCO 2009b. Ichkeul National Park, Available at: http://whc.unesco.org/en/list/8/

763 Vanderkelen I, van Lipzig NPM, Thiery A (2018) Modelling the water balance of Lake Victoria

764 (East Africa) - Part 1: Observational analysis. Hydrol. Earth Syst Sci.

765 https://doi.org/10.5194/hess-22-5509-2018

766 Yazidi A, Saidi S, Ben M'Barek N, Darragi F (2017) Contribution of GIS to evaluate surface

767 water pollution by heavy metals: Case of Ichkeul Lake (Northern Tunisia). J Afr Earth Sci.

768 https://doi.org/10.1016/j.jafrearsci.2017.06.009

769 Zedler JB, Kercher. 2005. WETLAND RESOURCES: Status Trends Ecosystem Services and

770 Restorability.

Ann

$\operatorname{Rev}$

Environ

Resour.

771 https://doi.org/10.1146/annurev.energy.30.050504.144248

772 


\section{Figure Caption}

775 Figure 1. Geographic location of Ichkeul Lake and localization of sampling stations

776 Figure 2. Land-Ocean Interaction in the Coastal Zone (LOICZ) budgeting procedure for the

777 Ichkeul Lake. $V_{P}$ : Precipitation volume $\left(\mathrm{m}^{3} \mathrm{~d}^{-1}\right), \mathrm{V}_{\mathrm{Q}}$ : runoff flow volume $\left(\mathrm{m}^{3} \mathrm{~d}^{-1}\right), \mathrm{V}_{0}$ : Other flow

778 volume $\left(\mathrm{m}^{3} \mathrm{~d}^{-1}\right), \mathrm{V}_{\mathrm{E}}$ : evaporation volume $\left(\mathrm{m}^{3} \mathrm{~d}^{-1}\right), \mathrm{V}_{\mathrm{G}}$ : Groundwater flow volume $\left(\mathrm{m}^{3} \mathrm{~d}^{-1}\right), \mathrm{V}_{\mathrm{R}}$ :

779 residual flow $\left(\mathrm{m}^{3} \mathrm{~d}^{-1}\right), \mathrm{V}_{\mathrm{X}}$ : Exchange flow $\left(\mathrm{m}^{3} \mathrm{~d}^{-1}\right)$.

780 Figure 3. Spatial distribution of physico-chemical parameters in winter (capital letter) and

781 summer (apostrophic capital letter) including Temperature (A, A'), Salinity (B, B') and

782 Dissolved Oxygen (C, C')

783 Figure 4. Spatial distribution of Chlorophyll a, phosphorous and nitrogen components in winter 784 (capital letter) and summer (apostrophic capital letter), including Total Phosphorous TP (A, A'),

785 Dissolved Inorganic Phosphorus DIP (B, B'), Total Nitrogen TN (C, C'), Dissolved Inorganic 786 Nitrogen DIN (D', D') and Chlorophyll a Chla (E, E')

787 Figure 5. Principal Component Analysis (PCA). Plots of the PCA performed for Chlorophyll $a$,

788 physical and chemical parameters according to the winter (A) and summer (A') with sampling 789 stations

790 Figure 6. Generalized box diagrams for seasonal changes in hydrology and biogeochemistry.

791 Figure 7. Generalized box diagrams illustrating DIP and DIN budgets in the winter (A, B) and 792 summer (A’, B’) respectively

\section{Supplementary material}

794 Figure SM1. Summary of the seasonal hydrological, biogeochemical and metabolic functioning 795 of the Ichkeul Lake wetland ecosystem 
Figures

\section{Figure 1}

Geographic location of Ichkeul Lake and localization of sampling stations

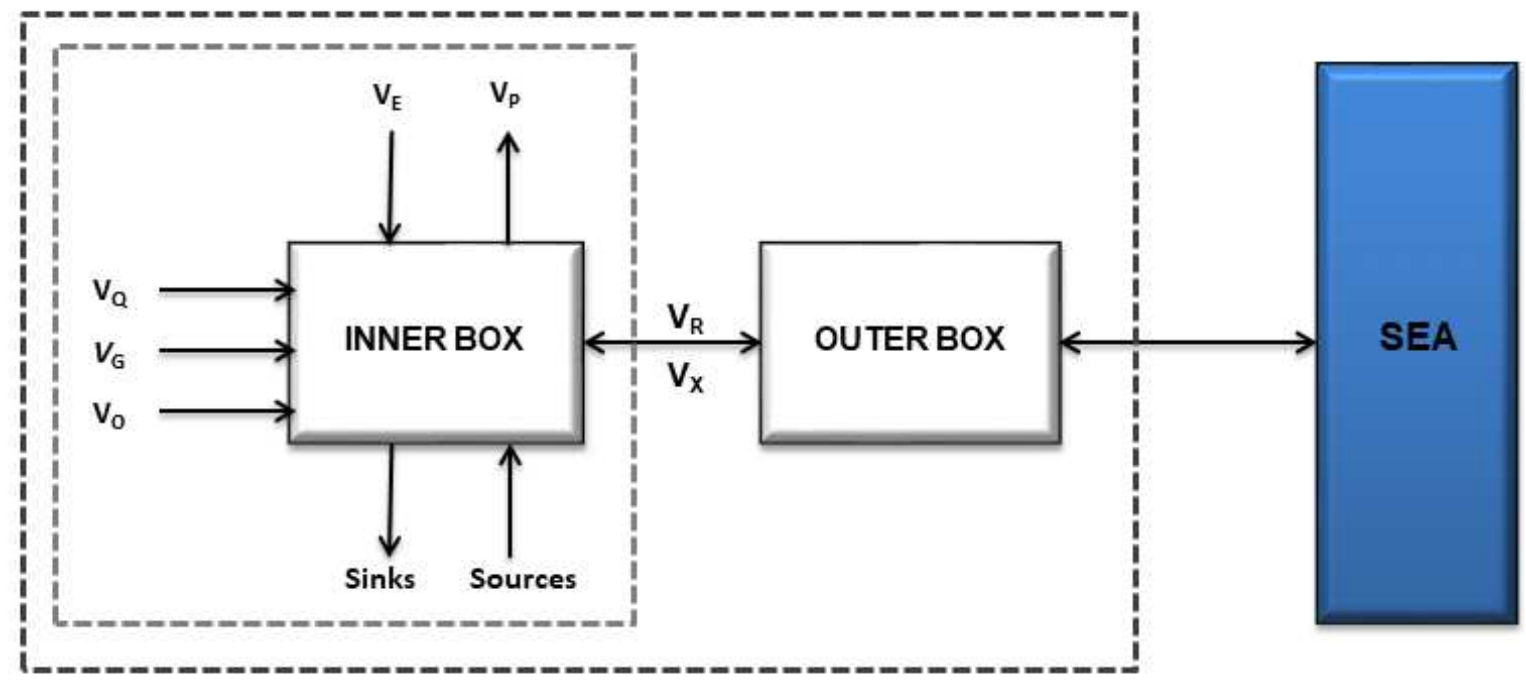

$V_{p}$ - Precipitation volume $\left(\mathrm{m}^{3} \mathrm{~d}^{-1}\right), \mathrm{V}_{\mathrm{Q}}$ - Runoff flow volume $\left(\mathrm{m}^{3} \mathrm{~d}^{-1}\right), \mathrm{V}_{\mathrm{o}}$ - Other flow volume $\left(\mathrm{m}^{3} \mathrm{~d}^{-1}\right)$, $V_{E}$ - Evaporation volume $\left(\mathrm{m}^{3} \mathrm{~d}^{-1}\right), \mathbf{V}_{\mathrm{G}}$ - Ground water flow volume $\left(\mathrm{m}^{3} \mathrm{~d}^{-1}\right), \mathbf{V}_{\mathrm{R}}$ - Residual flow $\left(\mathrm{m}^{3} \mathrm{~d}^{-1}\right)$, $V_{x}$ - Exchange flow $\left(\mathrm{m}^{3} \mathrm{~d}^{-1}\right)$.

Figure 2

Land-Ocean Interaction in the Coastal Zone (LOICZ) budgeting procedure for the Ichkeul Lake. $V_{P}$ : Precipitation volume $\left(\mathrm{m}^{3} \mathrm{~d}^{-1}\right), \mathrm{V}_{\mathrm{Q}}$ : runoff flow volume $\left(\mathrm{m}^{3} \mathrm{~d}^{-1}\right), \mathrm{V}_{0}$ : Other flow volume $\left(\mathrm{m}^{3} \mathrm{~d}^{-1}\right), \mathrm{V}_{\mathrm{E}}$ : evaporation volume $\left(m^{3} d^{-1}\right), v_{G}$ : Groundwater flow volume $\left(m^{3} d^{-1}\right), v_{R}$ : residual flow $\left(m^{3} d^{-1}\right), v_{X}$ : Exchange flow $\left(\mathrm{m}^{3} \mathrm{~d}^{-1}\right)$. 


\section{Figure 3}

Spatial distribution of physico-chemical parameters in winter (capital letter) and summer (apostrophic capital letter) including Temperature (A, $\left.A^{\prime}\right)$, Salinity $\left(B, B^{\prime}\right)$ and Dissolved Oxygen $\left(C, C^{\prime}\right)$

\section{Figure 4}

Spatial distribution of Chlorophyll a, phosphorous and nitrogen components in winter (capital letter) and summer (apostrophic capital letter), including Total Phosphorous TP (A, A'), Dissolved Inorganic Phosphorus DIP (B, B'), Total Nitrogen TN (C, C'), Dissolved Inorganic Nitrogen DIN ( $\left.D^{\prime}, D^{\prime}\right)$ and Chlorophyll a $\operatorname{Chla}\left(\mathrm{E}, \mathrm{E}^{\prime}\right)$

\section{Figure 5}

Principal Component Analysis (PCA). Plots of the PCA performed for Chlorophyll a, physical and chemical parameters according to the winter $(A)$ and summer $\left(A^{\prime}\right)$ with sampling stations 
Winter

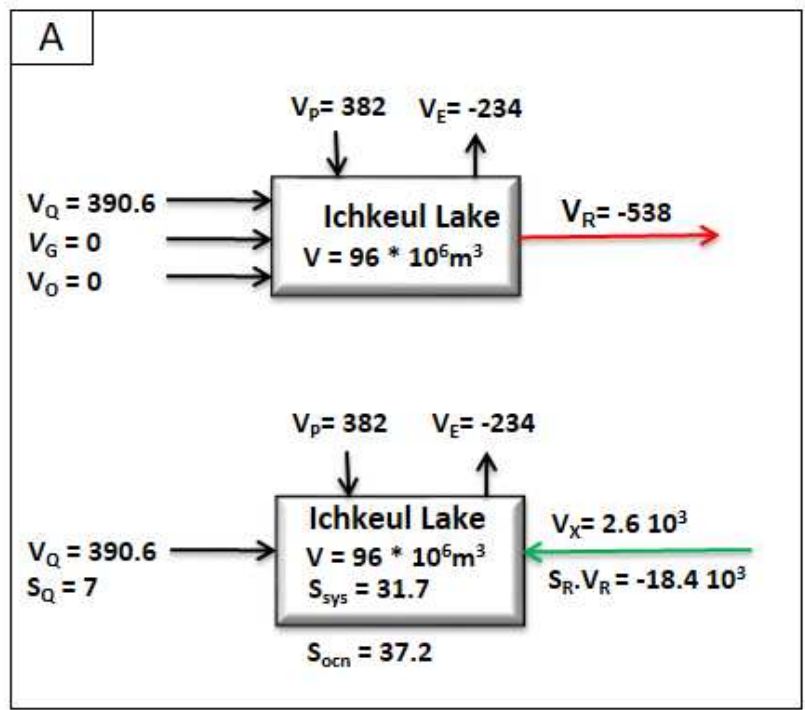

Summer

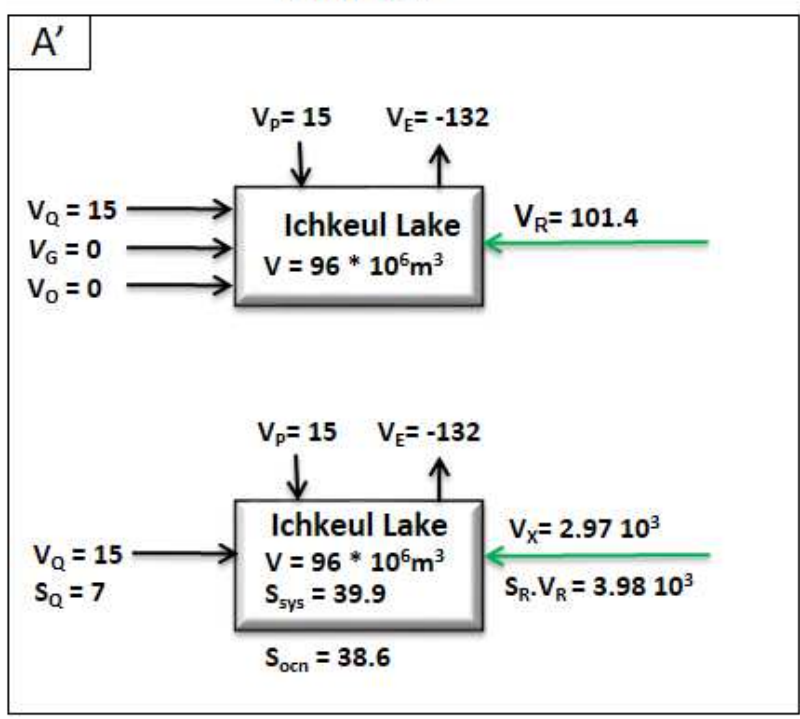

\section{Figure 6}

Generalized box diagrams for seasonal changes in hydrology and biogeochemistry. 
Winter
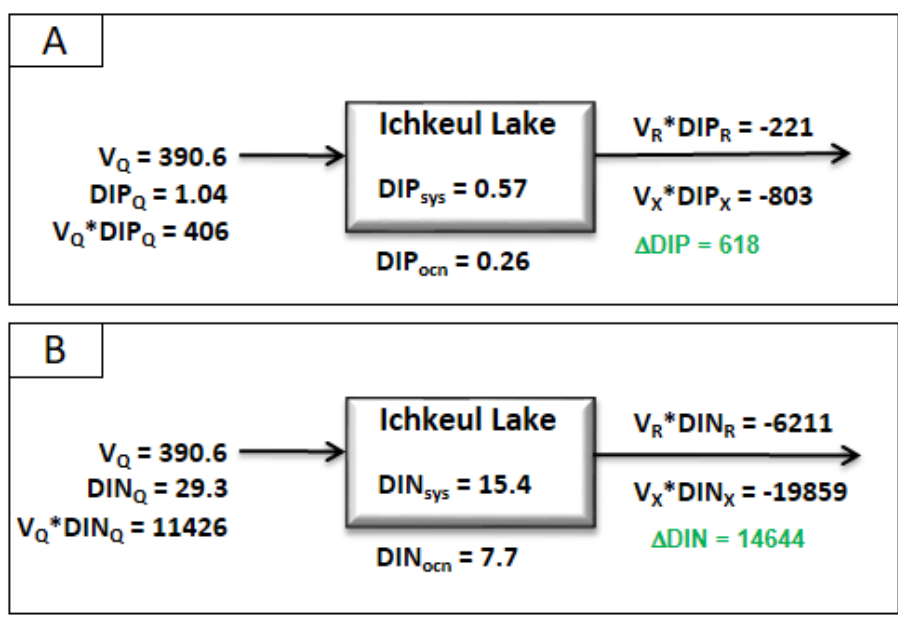

Summer
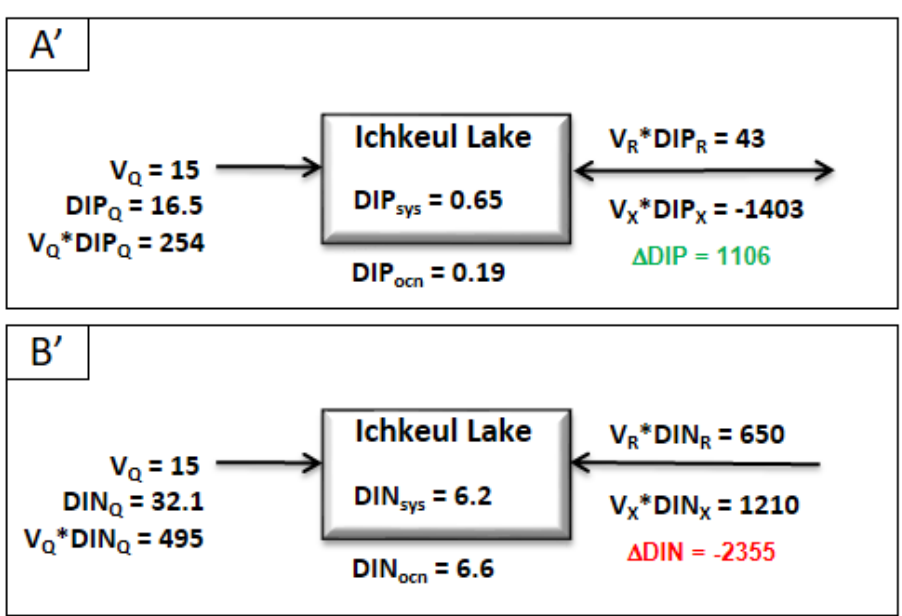

Figure 7

Generalized box diagrams illustrating DIP and DIN budgets in the winter $(A, B)$ and summer $\left(A^{\prime}, B^{\prime}\right)$ respectively

\section{Supplementary Files}

This is a list of supplementary files associated with this preprint. Click to download.

- LOICZIchkeulNatureSR.png 